\title{
Thermal inactivation analysis of water-related pathogens in domestic hot water systems
}

\author{
Liam McCarton \\ Technological University Dublin, liam.mccarton@tudublin.ie \\ Sean O'hOgain \\ Technological University Dublin, Sean.Ohogain@tudublin.ie
}

Follow this and additional works at: https://arrow.tudublin.ie/engschcivart

Part of the Civil and Environmental Engineering Commons

\section{Recommended Citation \\ Mccarton, Liam \& O Hogain, Sean. (2017). Thermal inactivation analysis of water-related pathogens in domestic hot water systems. Journal of Environmental Engineering and Science. 12. 1-8. 10.1680/ jenes.16.00028.}

This Article is brought to you for free and open access by the School of Civil and Structural Engineering at ARROW@TU Dublin. It has been accepted for inclusion in Articles by an authorized administrator of ARROW@TU Dublin. For more information, please contact arrow.admin@tudublin.ie, aisling.coyne@tudublin.ie, gerard.connolly@tudublin.ie.

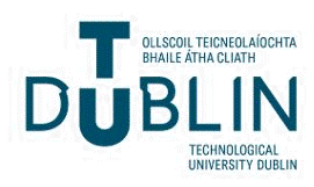


Journal of Environmental Engineering and Science

Volume 12 Issue JS2

Thermal inactivation analysis of waterrelated pathogens in domestic hot water systems

McCarton and $\mathrm{O}^{\prime}$ Hogain
Journal of Environmental Engineering and Science, 2017, 12(2), 34-41 http://dx.doi.org/10.1680/jenes. 16.00028 Paper 16.00028

\section{Thermal inactivation analysis of water-related pathogens in domestic hot water systems}

Liam McCarton BEng, MEngSc, CEng

Lecturer, School of Civil and Structural Engineering, Dublin Institute of

Technology, Dublin, Ireland (corresponding author: liam.mccarton@dit.ietel) (Orcid:0000-0002-7893-7392)
Sean O'Hogain PhD

Lecturer, School of Civil and Structural Engineering, Dublin Institute of

Technology, Dublin, Ireland (Orcid:0000-0001-7192-8349)

This study aims to investigate whether hot water systems supplied with harvested rainwater present an increased risk to health over hot water systems supplied with potable mains water. It reviews previous studies investigating the health effects of utilising rainwater within domestic systems. The main risk to public health of mains-supplied hot water systems is the operation, maintenance, age, location and temperature of the system. Rainwater-harvesting systems contain an inherent water treatment train consisting of flocculation, settlement, sorption and bioreaction, and stored rainwater quality improves as metal and chemical contaminants settle to form sludge. Laboratory experiments were conducted using a variety of water-related bacteria to determine the time required to reduce a bacterial population by $90 \%$ at a given temperature. The results of this study show that after 5 min of exposure at 60 and $55^{\circ} \mathrm{C}$, respectively, Salmonella, Pseudomonas aeruginosa and total viable count at 22 and $37^{\circ} \mathrm{C}$ concentrations were reduced to zero. Irish standards require hot water systems to be maintained at temperatures at or above $60^{\circ} \mathrm{C}$. The conclusion from this pilot study is that hot water systems supplied with harvested rainwater do not present an increased risk to health over hot water systems fed with mains water.

\section{Introduction}

In Ireland, all public water supply is treated to potable standards, and harvested rainwater (RWH) is considered only for nonpotable uses (toilet flushing). Hot water systems represent approximately $20 \%$ of household per capita consumption in Ireland and represent a logical extension for the use of RWH to reduce mains water demand (O'Hogain et al., 2007). This study sets out to investigate whether hot water systems supplied with RWH present an increased risk to health over hot water systems supplied with potable mains water. It also reviews previous studies investigating the health effects of utilising RWH within domestic systems (O'Hogain et al., 2011, 2012). The paper also presents the results from laboratory experiments conducted using a variety of water-related bacteria to determine the time required to reduce a bacterial population by $90 \%$ at a given temperature.

\section{Health concerns}

The most common source of pathogens in drinking water supplies is recent contamination by human and/or animal excreta (Prescott et al., 1993). Pathogens of concern include bacteria, viruses and protozoa that can cause gastroenteritis, diarrhoea, dysentery, hepatitis, cholera or typhoid fever (NHMRC, 1996). While the majority of waterborne diseases are caused by pathogens that originate in the gastrointestinal tracts of humans or animals, there are microbes existing in the environment that can, in some cases, cause disease in humans (Prescott et al., 1993). Escherichia coli are a common intestinal bacteria found in large concentrations within warm-blooded animals. E. coli are commonly used as indicator organisms, indicating evidence of faecal material (WHO, 2003). Salmonella spp. are a group of human pathogens that can infect the gastrointestinal tract of humans, causing diarrhoea (Prescott, 1993). Pseudomonas aeruginosa is an opportunistic pathogen that may cause infection through skin lesions (WHO, 2003). Enterococcus spp. is an anaerobic bacterial genus that is a commensal inhabitant of the human intestine. It is reported to provide a higher correlation with many of the human pathogens found in wastewater than faecal coliforms (Jin et al., 2004).

\section{Persistence and growth in water}

While typical waterborne pathogens are able to persist in drinking water, most do not grow or proliferate in water. Microorganisms such as E. coli can accumulate in sediments and are mobilised when water flow increases. After leaving the body of their host, most pathogens gradually lose viability and the ability to infect (Prescott et al., 1993). The rate of decay is usually exponential, and a pathogen will become undetectable after a certain period. Pathogens with low persistence must rapidly find new hosts. Persistence is affected by several factors, of which temperature is the most important. Decay is usually faster at higher temperatures, hence, the term 'thermal inactivation'. For pathogen-contaminated water to cause illness in humans, the pathogens must have an available route of infection and must overcome the defence barriers of the human body (stomach acidity, competition by natural gut flora and immunological responses, including acquired immunity). Routes of infection may include inhalation or ingestion. Successful infection by the pathogen is ultimately dependent on the pathogen dose (Prescott et al., 1993).

\section{Public health risks associated with rainwater harvesting} About three million Australians use roof-harvested rainwater from tanks for drinking in urban and rural regions (ABS, 1994). Fuller et al. (1981), Mobbs et al. (1998) and Cunliffe (1998) found that the quality of rainwater was often adequate for potable uses provided the rainwater tank and roof catchment were subject to 
Journal of Environmental Engineering

and Science

Volume 12 Issue JS2
Thermal inactivation analysis of water-

related pathogens in domestic hot water

systems

McCarton and O'Hogain adequate maintenance (Coombes et al., 2002). Studies from both Ireland (O'Hogain et al., 2012) and New Zealand (Simmons et al., 2001) found that the RWH supplies sometimes exceeded drinking water guidelines for lead and microbial indicator organisms. Cunliffe (1998) stated that the probable source of indicator bacteria detected in rainwater tanks was excreta from small animals and birds. Of the epidemiological studies conducted on rainwater to date, two have compared the rates of gastroenteritis in young children. A study of cryptosporidiosis notifications in South Australia found a significantly reduced risk of cryptosporidiosis associated with tank rainwater compared to public mains water (Weinstein et al., 1993). A cohort study of 1016 4- to 6-year-olds, who were regular consumers of tank rainwater, concluded that they were at no greater risk of gastroenteritis than those who drank treated public mains water (Heyworth et al., 2006). The majority of rainwater tanks in this study were galvanised iron (59\%) with $43 \%$ of tanks greater than 10 years old. Only $8 \%$ of the tanks had first-flush devices, and sludge was never removed in $42 \%$ of the tanks (Heyworth et al., 2006). A pooled epidemiological study of 13 case studies, which quantified the risk of gastrointestinal disease from rainwater consumption, concluded that there was no significant difference in risk comparing rainwater to improved water supplies (Dean and Hunter, 2012). A double-blinded randomised controlled trial among 300 households in Adelaide, South Australia, concluded that there were no appreciable differences in health outcomes from drinking untreated or treated rainwater (Rodrigo et al., 2011). Ahmed et al. (2011) carried out a review of available research reporting the microbial quality of RWH. This review suggested that the quality of RWH is strongly influenced by the season and the number of preceding dry days (Kus et al., 2010; Lye, 2009). Several of the case studies reviewed suggested links between gastroenteritis and consumption of untreated rainwater (Brodribb et al., 1995; Franklin et al., 2008; Murrell and Stewart, 1983). These reported outbreaks tended to involve small numbers of individuals, and the reported illnesses were often related to communal RHW systems.

Coombes (2015) hypothesised that RWH contains an inherent water treatment process ('treatment train') consisting of flocculation, settlement, sorption and bioreaction and that stored rainwater quality improves as metal and chemical contaminants settle to form sludge. This study highlighted the importance of first-flush devices to remove $11-94 \%$ of dissolved solids and $62-97 \%$ of suspended solids from the first $0.25 \mathrm{~mm}$ of roof runoff. Martin et al. (2010) assessed the microbial properties of RWH at two study sites at Newcastle on the east coast of Australia. They concluded that rainfall events contributed to the bacterial load in rainwater storage systems, but that processes within the rainwater storage ensured that these incoming loads were not sustained. Spinks et al. (2005) and Spinks (2007) concluded that biofilms that formed on RWH tank walls and at the base of the sludge layer act to improve water quality. Spinks (2007) concludes that the settlement of particulate matter to the bottom of rainwater tanks is probably the single most beneficial process within rainwater storage. The quality of rainwater supplies was not compromised by the accumulation of sludge in tanks. This confirms the observation by Coombes (2002) that it is preferable to avoid disturbing rainwater storages.

Further studies (Morrow et al., 2007, 2010) concluded that the majority of the rainwater-harvesting systems in national investigations were compliant with the chemical and metal values in Australian Drinking Water Guidelines. Given the variability of RWH quality throughout the system, the most reliable sampling location is point the of use for a given end use. Evans et al. (2009) used pioneering medical science techniques including polymerase chain reaction (PCR) methods (not experimental real-time analysis) to extract deoxyribonucleic acid (ribonucleic acid) of microbes in over 40 rainwater harvesting systems over a 3 -year period. Each sample was also subjected to a comprehensive range of microbial, medical and biochemical tests to confirm the results of the PCR analysis. The research found that bacteria of faecal origin were rare and not abundant or persistent in rainwater harvesting systems. This research discovered that rainwater storages act as balanced ecosystems in a similar fashion to environmental systems that improve water quality (Evans et al., 2009).

\section{Hot water systems}

Arguably, the most significant health risk in hot water systems comes from the respiratory pathogen Legionella pneumophila. $L$. pneumophila is the agent of Legionnaires disease, an acute form of pneumonia, which most commonly infects the respiratory tract of immunocompromised individuals. While L. pneumophila can be due to aspiration, the most likely route of infection of the respiratory tract occurs when the bacteria is entrapped in aerosols and inhaled. The ingestion of L. pneumophila is harmless as they are unable to cope with the stresses of the gastrointestinal tract. There may be a potential health risk from showering in hot water if the water supply contains $L$. pneumophila and the hot water is maintained below $60^{\circ} \mathrm{C}$, as contaminated aerosols may be produced. However, this risk is equally applicable to mains water users. Thermal inactivation can be used as an effective method to inactivate Legionella bacteria. The degree of inactivation is dependent on the temperature and the length of time the bacteria are exposed to that temperature. The thermal inactivation of Legionella bacteria starts around $50^{\circ} \mathrm{C}$ but is more rapid at higher temperatures. At $60^{\circ} \mathrm{C}, 90 \%$ of $L$. pneumophila will be inactive after $3.2 \mathrm{~min}$ of exposure (average value) (Makin, 2014). Where the water contains $100000 \mathrm{CFU} / 1$ Legionella, the bacteria need to be held at $60^{\circ} \mathrm{C}$ for approximately $10 \mathrm{~min}$ to reduce numbers to below UK's Health and Safety Executive (HSE) action level of $100 \mathrm{CFU} / 1$. Hot water storage cylinders that maintain a temperature of $60^{\circ} \mathrm{C}$ throughout the whole storage vessel for a period of $1 \mathrm{~h}$ daily should achieve satisfactory control of Legionella bacteria, in line with the recommendations in UK's HSE code of practice (HSE, 2013). A study by Borella et al. (2004) investigated Legionella spp. and Pseudomonas spp. contamination of hot water systems in Italy. Legionella spp. and Pseudomonas spp. were detected in 22.6 and $38.4 \%$ of samples, respectively. The study found that system and building 
Journal of Environmental Engineering

and Science

Volume 12 Issue JS2
Thermal inactivation analysis of water-

related pathogens in domestic hot water

systems

McCarton and O'Hogain characteristics were the main predictors for Legionella. Legionella contamination was associated with a centralised heater, distance from the heating point of $>10 \mathrm{~m}$ and a water plant that is $>10$ years old. Legionella presence was not affected by the origin of water (Borella, 2004). A study by Kruse (2015) in Germany analysed water samples from 718 buildings for Legionella spp. The study concluded that the most important risk factor for contamination with Legionella spp. was the temperature of the circulated hot water.

\section{Heat inactivation rates for waterborne disease}

While extensive research has been undertaken in the food industry to determine the heat inactivation rates for pathogens, studies for thermal inactivation in a freshwater medium are more recent and more specialised (Spinks et al., 2005). Spinks et al. (2006) carried out thermal inactivation analyses on eight species of non-sporeforming bacteria in a water medium at temperatures of $55-65^{\circ} \mathrm{C}$, and susceptibilities to heat stress were compared using $D$-values. The $D$-value for this study was defined as the time required to reduce a bacterial population by $90 \%$ or $1 \log$ reduction. The results suggested that the temperature range from $55-65^{\circ} \mathrm{C}$ was critical for the effective elimination of enteric/pathogenic bacterial components and supported the thesis that hot water systems should operate at a minimum of $60^{\circ} \mathrm{C}$. The study also recommended that future rainwater harvesting investigations should focus on the microbial ecology of rainwater treatment trains and stored water to determine the types of organisms likely to exist in these systems. Ahmed et al. (2011) also concluded that any microbial assessment should involve the analysis of RWH for actual pathogenic species, not just the common faecal indicator bacteria. Coombes et al. (2006) and Evans et al. (2006) further highlighted that $E$. coli has a large number of non-faecal environmental strains that are prevalent in natural waters (such as rainwater). Later research by Luo et al. (2011) confirmed this key issue - that the isolation of $E$. coli in rainwater may not indicate faecal contamination.

\section{Methodology}

This study sets out to determine the time required to reduce a bacterial population by $90 \%$ at a given temperature. Analysis was carried out to assess the thermal destruction rates of sterile water samples spiked with known quantities of bacteria and to show the suitability of rainwater as an alternative hot water supply within the domestic house. The temperatures chosen were 55 and $60^{\circ} \mathrm{C}$ as they mimic the conditions typically found in a domestic hot water system. Aliquots of the spiked water samples were taken at times 0 , $5,10,15$ and $20 \mathrm{~min}$ and processed for a concentration of bacteria. The bacteria chosen for the experiments included E. coli, Enterococcus fecalis, P. aeruginosa and Salmonella spp. They are all indicators of water quality, in particular, E. coli and faecal coliforms which are indicators of faecal pollution. E. coli were measured using the method employed by the Irish National Accreditation Board (Inab)-accredited laboratory using the Colilert 18 method, a most probable number (MPN) technique that is suitable for the examination of drinking waters, including samples from all stages of treatment and distribution, and those source waters of moderate to high turbidity (Idexx, 2012a). This method was chosen as it is the only US Environmental Protection Agencyapproved $18 \mathrm{~h}$ test and is included in the Standard Methods for Examination of Water and Wastewater (Idexx, 2012a). Faecal coliforms were measured using a method based on those recommended in the 21st edition of Standard Methods for the Examination of Water and Wastewater (American Public Health Association et al., 2005). Pseudomonas spp. were measured using a method based on the Microbiology of Drinking Water - Part 8 (Gov.uk, 2010), and the medium used was Pseudomonas Isolation Agar. Filtered samples were incubated at $37 \pm 1^{\circ} \mathrm{C}$ for $48 \mathrm{~h}$. The colony count of heterotrophic bacteria or total viable count $\left(T_{\mathrm{VC}}\right)$ was enumerated by the Inab-accredited testing laboratory using the pour plate method with yeast extract agar (Idexx, 2012b). Salmonella spp. were chosen as an extra parameter for these experiments as it is a human pathogen that can infect the gastrointestinal tract of humans causing diarrhoea (Prescott, 1993). The method employed by the laboratory for the detection of Salmonella spp. was that of the Tecra Unique Salmonella Kit.

The bacteria used for spiking the water samples were obtained from the Health Protection Agency in the UK. They were supplied in lenticule discs and were then reconstituted using sterile phosphate buffer solution. Lenticule is the registered trademark name for the reference materials supplied by Public Health England. These are mainly used as controls for food, water and environmental microbiology examination.

The water samples were spiked by transferring the shaken reconstituted Lenticule of known bacteria into sterile water. This was then analysed for colifoms, E. coli, faecal coliforms, Salmonella, P. aeruginosa and $T_{\mathrm{VC}}$ at 22 and $37^{\circ} \mathrm{C}$. Once the first aliquot was taken, the spiked water sample was placed in a heated water bath at $55^{\circ} \mathrm{C}$. A calibrated temperature probe was placed in a control sample of water placed alongside the samples in the water bath in order to record the temperatures at given intervals of $5,10,15$ and $20 \mathrm{~min}$. Once the desired temperature of $55^{\circ} \mathrm{C}$ was reached, a timer was set for each of the 5 min intervals. Sample aliquots were then taken and analysed for the methods specified earlier. For the heat treatment experiments at $60^{\circ} \mathrm{C}$, the same procedure as outlined earlier was repeated with the spiked water sample placed in a heated water bath at $60^{\circ} \mathrm{C}$. All water samples were incubated at $60^{\circ} \mathrm{C}$ for $5,10,15$ and $20 \mathrm{~min}$, respectively. Samples were analysed immediately following treatment.

\section{Results}

Thermal inactivation experiments conducted at $55^{\circ} \mathrm{C}$ Table 1 shows the microbiological results for coliforms, E. coli, faecal coliforms, Salmonella, $P$. aeruginosa and $T_{\mathrm{VC}}$ (at 22 and $37^{\circ} \mathrm{C}$ ). All samples were incubated at $55^{\circ} \mathrm{C}$ for $5,10,15$ and $20 \mathrm{~min}$, respectively. The sample was taken prior to heat treatment at $55^{\circ} \mathrm{C}$. Both the coliform and E. coli results were $248 \cdot 3 \mathrm{MPN} / 100 \mathrm{ml}$. After $5 \mathrm{~min}$ at $55^{\circ} \mathrm{C}$, the values showed a marked decrease to $2 \cdot 1 \mathrm{MPN} /$ 
Volume 12 Issue JS2
Thermal inactivation analysis of waterrelated pathogens in domestic hot water systems

McCarton and O'Hogain

Table 1. Overall microbiological results for heat treatment experiments at $55^{\circ} \mathrm{C}$

\begin{tabular}{|c|c|c|c|c|c|c|}
\hline \multirow{2}{*}{ Parameter } & \multirow{2}{*}{ Unit } & \multicolumn{5}{|c|}{ Time: $\min$} \\
\hline & & 0 & 5 & 10 & 15 & 20 \\
\hline Coliforms & MPN/100 ml & $248 \cdot 3$ & $2 \cdot 1$ & 0 & 0 & 0 \\
\hline E. coli & MPN/100 ml & $248 \cdot 3$ & $2 \cdot 1$ & 0 & 0 & 0 \\
\hline$T_{\mathrm{VC}}$ at $22^{\circ} \mathrm{C}$ & CFU/ml & 88 & 0 & 0 & 0 & 0 \\
\hline$T_{\mathrm{VC}}$ at $37^{\circ} \mathrm{C}$ & CFU/ml & 101 & 0 & 0 & 0 & 0 \\
\hline P. aeruginosa & CFU/ml & 12 & 0 & 0 & 0 & 0 \\
\hline
\end{tabular}

$100 \mathrm{ml}$. At all other times, 10, 15 and $20 \mathrm{~min}$, respectively, no coliforms or $E$. coli were detected in the samples. $T_{\mathrm{VC}}$ at 22 and $37^{\circ} \mathrm{C}$ was also highest at time $0,88 \mathrm{CFU} / \mathrm{ml}$ at $22^{\circ} \mathrm{C}$ and $101 \mathrm{CFU} /$ $\mathrm{ml}$ at $37^{\circ} \mathrm{C}$. After $5 \mathrm{~min}$, no $T_{\mathrm{VC}}$ at 22 or $37^{\circ} \mathrm{C}$ was detected.

\section{Coliforms and E. coli}

The coliforms and $E$. coli samples taken prior to heat treatment at $55^{\circ} \mathrm{C}$ gave a concentration of $248 \cdot 3 \mathrm{MPN} / 100 \mathrm{ml}$, as shown in Figure 1. After $5 \mathrm{~min}$ at $55^{\circ} \mathrm{C}$, results showed a dramatic decrease to $2 \cdot 1 \mathrm{MPN} / 100 \mathrm{ml}$. At times 10,15 and $20 \mathrm{~min}$, no coliforms or E. coli were detected in the samples.

\section{Faecal coliforms}

The thermal inactivation rates for faecal colifoms at $55^{\circ} \mathrm{C}$ are shown in Figure 2. Faecal coliforms at time 0 prior to heat treatment at $55^{\circ} \mathrm{C}$ was $36 \mathrm{CFU} / \mathrm{ml}$. After $5 \mathrm{~min}$ at $55^{\circ} \mathrm{C}$, results showed a dramatic decrease to $0 \mathrm{CFU} / \mathrm{ml}$. At times 10,15 and $20 \mathrm{~min}$, no faecal coliforms were detected in the samples.

\section{$T_{\mathrm{Vc}}$}

The thermal inactivation rates for $T_{\mathrm{VC}}\left(22\right.$ and $\left.37^{\circ} \mathrm{C}\right)$ at $55^{\circ} \mathrm{C}$ are shown in Figure 3. $T_{\mathrm{VC}}$ at 22 and $37^{\circ} \mathrm{C}$ prior to heat treatment at time 0 was $88 \mathrm{CFU} / \mathrm{ml}$ at $22^{\circ} \mathrm{C}$ and $101 \mathrm{CFU} / \mathrm{ml}$ at $37^{\circ} \mathrm{C}$. After

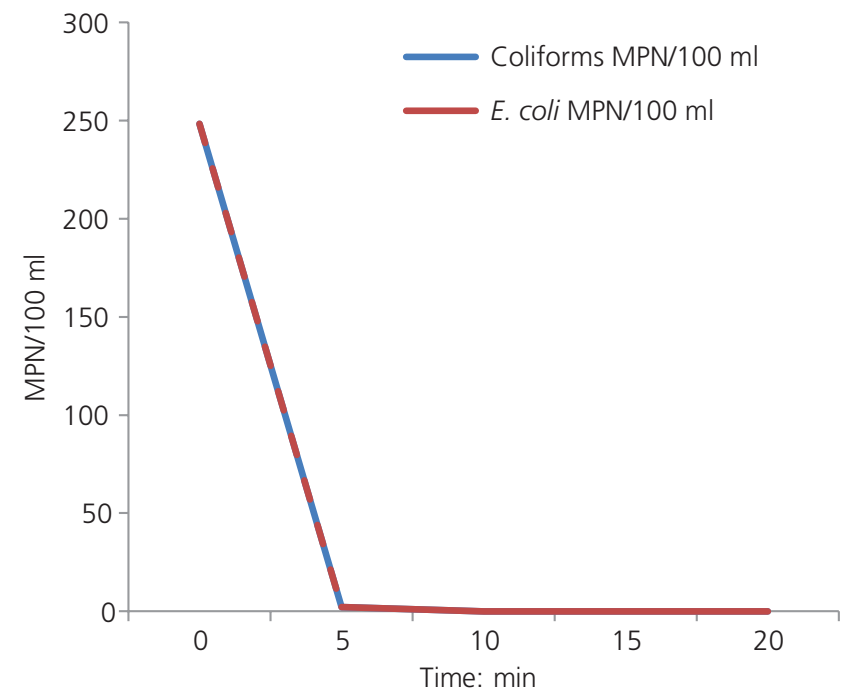

Figure 1. Thermal inactivation rates for coliforms and E. coli at $55^{\circ} \mathrm{C}$

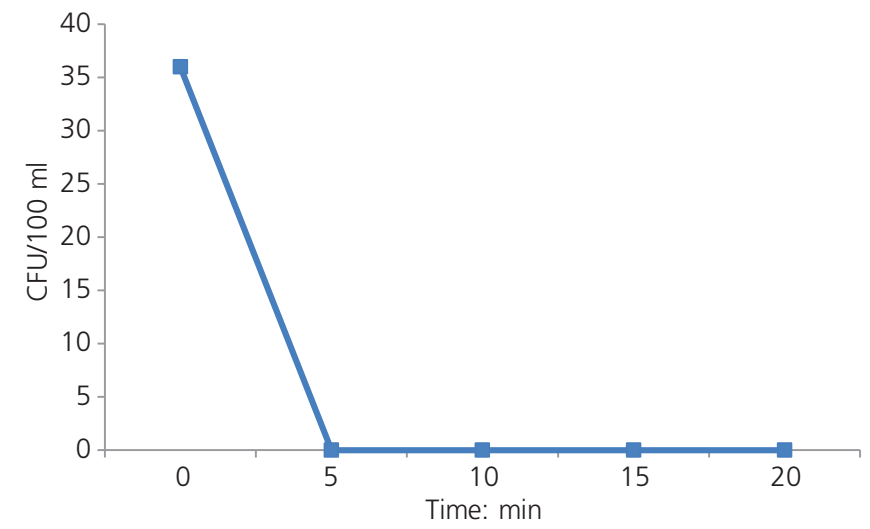

Figure 2. Thermal inactivation rates for fecal colifoms at $55^{\circ} \mathrm{C}$

$5 \mathrm{~min}$, no $T_{\mathrm{VC}}$ at either 22 or $37^{\circ} \mathrm{C}$ was detected and none thereafter at times 10,15 or $20 \mathrm{~min}$.

\section{Pseudomonas aeruginosa}

The thermal inactivation rates for $P$. aeruginosa at $55^{\circ} \mathrm{C}$ are shown in Figure 4. P. aeruginosa prior to heat treatment at time 0

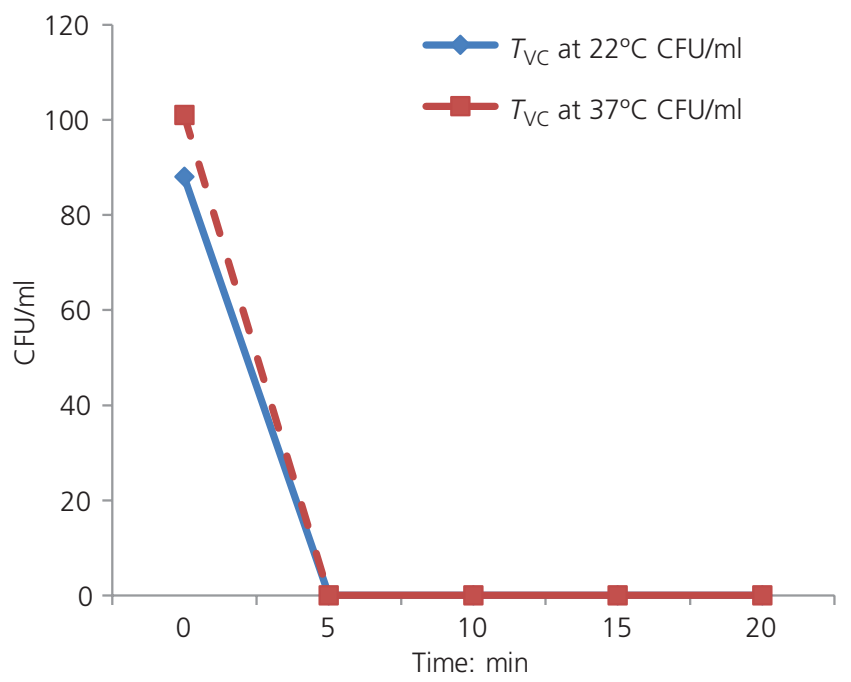

Figure 3. Thermal inactivation rates for $T_{\mathrm{Vc}}\left(22\right.$ and $\left.37^{\circ} \mathrm{C}\right)$ at $55^{\circ} \mathrm{C}$ 
Thermal inactivation analysis of waterrelated pathogens in domestic hot water systems

McCarton and O'Hogain

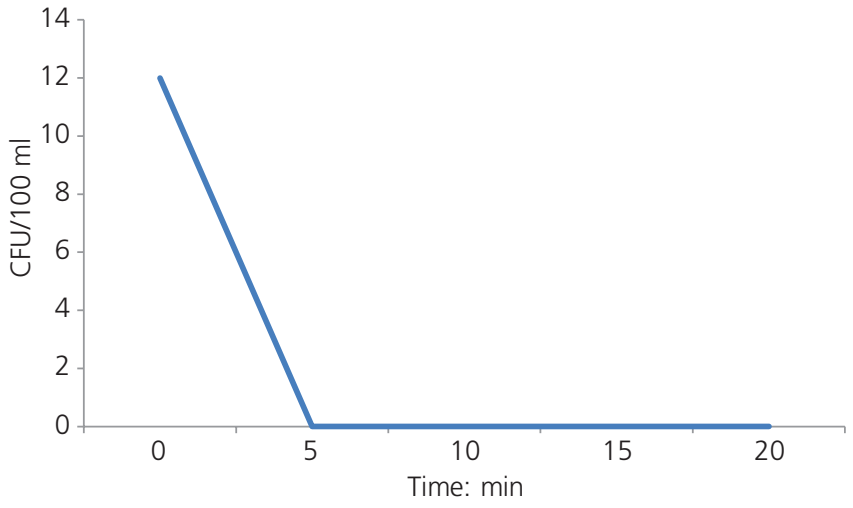

Figure 4. Thermal inactivation rates for $P$. aeruginosa at $55^{\circ} \mathrm{C}$

was $12 \mathrm{CFU} / 100 \mathrm{ml}$. P. aeruginosa was not detected at 5, 10, 15 or $20 \mathrm{~min}$.

\section{Thermal inactivation experiments conducted at $60^{\circ} \mathrm{C}$}

Table 2 shows the microbiological results for coliforms, E. coli, faecal coliforms, Salmonella, P. aeruginosa and $T_{\mathrm{VC}}$ at 22 and $37^{\circ} \mathrm{C}$.

\section{Coliforms and E. coli}

The thermal inactivation rates for coliform and E. coli at $60^{\circ} \mathrm{C}$ are shown in Figure 5. The coliforms and E. coli samples taken prior to heat treatment at $60^{\circ} \mathrm{C}$ gave a concentration of $261.3 \mathrm{MPN} /$ $100 \mathrm{ml}$. After $5 \mathrm{~min}$, and thereafter at times 10,15 and $20 \mathrm{~min}$, no coliforms or E. coli were detected in the samples.

\section{Faecal coliforms}

The thermal inactivation rates for faecal coliform at $60^{\circ} \mathrm{C}$ are shown in Figure 6. Faecal coliform sample taken prior to heat treatment at $60^{\circ} \mathrm{C}$ gave a concentration of $34 \mathrm{CFU} / \mathrm{ml}$. After $5 \mathrm{~min}$ at $60^{\circ} \mathrm{C}$, the results showed a dramatic decrease to $0 \mathrm{CFU} / \mathrm{ml}$. At times 10,15 and $20 \mathrm{~min}$, no faecal coliforms were detected in the samples.

\section{$T_{\text {vc }}$ at 22 and $37^{\circ} \mathrm{C}$}

The thermal inactivation rates for $T_{\mathrm{VC}}\left(22\right.$ and $\left.37^{\circ} \mathrm{C}\right)$ at $60^{\circ} \mathrm{C}$ are shown in Figure 7. $T_{\mathrm{VC}}$ at 22 and $37^{\circ} \mathrm{C}$ prior to heat treatment at time 0 was $90 \mathrm{CFU} / \mathrm{ml}$ at $22^{\circ} \mathrm{C}$ and $129 \mathrm{CFU} / \mathrm{ml}$ at $37^{\circ} \mathrm{C}$. After 5 min, no $T_{\mathrm{VC}}$ at 22 or $37^{\circ} \mathrm{C}$ were detected and none thereafter at times 10,15 or $20 \mathrm{~min}$.

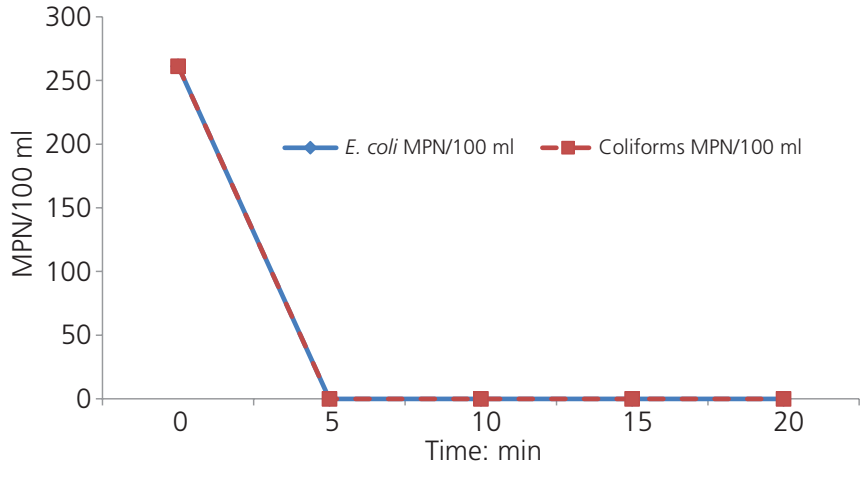

Figure 5. Thermal inactivation rates for coliform and $E$. coli at $60^{\circ} \mathrm{C}$

\section{Pseudomonas aeruginosa}

The thermal inactivation rates for $P$. aeruginosa at $60^{\circ} \mathrm{C}$ are shown in Figure 8. P. aeruginosa prior to heat treatment at time 0 was $15 \mathrm{CFU} / 100 \mathrm{ml}$. No $P$. aeruginosa was detected at 5, 10, 15 or $20 \mathrm{~min}$.

\section{Discussion of results}

\section{Simulating heat shock}

The results of this study indicate that after $5 \mathrm{~min}$ of exposure at 60 and $55^{\circ} \mathrm{C}$ respectively, E. coli, faecal coliforms, Salmonella, P. aeruginosa and $T_{\mathrm{VC}}$ at 22 and $37^{\circ} \mathrm{C}$ concentrations will have been reduced to zero. The mechanism of cell inactivation would appear to be the breakage of bonds due to excessive energy. Previous studies have shown that bacterial cells cultured at higher temperatures display more resistance to heat than bacteria cultures at lower temperature (Pflug and Holcomb, 1991). Thus, the results from this study may be conservative when compared to the typical lower temperature of water stored in rainwater harvesting tanks.

\section{Comparison with other similar studies}

These results are comparable with the results from international studies reported on similar experiments (Spinks et al., 2003). In this study, laboratory experiments investigated the time required to reduce a bacterial population by $90 \%$ or $1 \log$ reduction ( $D$-value) at 65,60 and $55^{\circ} \mathrm{C}$. The results reported $D$-values at 65 and $60^{\circ} \mathrm{C}$ for $E$. coli of 3 and $62 \mathrm{~s}$, respectively, while at $55^{\circ} \mathrm{C}$, E. coli displayed an initial $D$-value of $21 \mathrm{~min}$ followed by $4 \mathrm{~min}$.

Table 2. Overall microbiological results for heat treatment experiments at $60^{\circ} \mathrm{C}$

\begin{tabular}{|c|c|c|c|c|c|c|}
\hline \multirow{2}{*}{ Parameter } & \multirow{2}{*}{ Unit } & \multicolumn{5}{|c|}{ Time: $\min$} \\
\hline & & 0 & 5 & 10 & 15 & 20 \\
\hline Coliforms & MPN/100 ml & $261 \cdot 3$ & 0 & 0 & 0 & 0 \\
\hline E. coli & MPN/100 ml & $261 \cdot 3$ & 0 & 0 & 0 & 0 \\
\hline$T_{\text {VC }}$ at $22^{\circ} \mathrm{C}$ & CFU/ml & 90 & 0 & 0 & 0 & 0 \\
\hline$T_{\text {VC }}$ at $37^{\circ} \mathrm{C}$ & CFU/ml & 129 & 0 & 0 & 0 & 0 \\
\hline Pseudomonas & CFU/ml & 15 & 0 & 0 & 0 & 0 \\
\hline Faecal coliforms & CFU/ml & 34 & 0 & 0 & 0 & 0 \\
\hline
\end{tabular}


Thermal inactivation analysis of waterrelated pathogens in domestic hot water systems

McCarton and O'Hogain

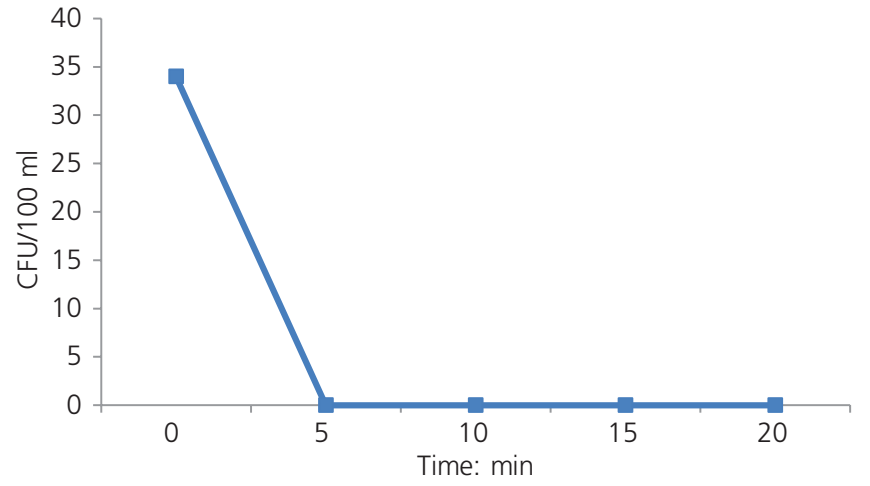

Figure 6. Thermal inactivation rates for faecal coliform at $60^{\circ} \mathrm{C}$

For $P$. aeruginosa, the $D$-value at 65,60 and $55^{\circ} \mathrm{C}$ were 5 and $49 \mathrm{~s}$ and $5 \mathrm{~min}$; for $S$. typhimurium, $<2,4$ and $77 \mathrm{~s}$; and for Klebsiella pneumoniae, $<2,<2$, and $35 \mathrm{~s}$, respectively. The results indicate that after $12 \mathrm{~min}$ at $60^{\circ} \mathrm{C}, \mathrm{E}$. coli concentrations will have been reduced by $15 \log$ reductions, while the other pathogens experienced similar or even greater reductions.

Human pathogens are restricted to temperature ranges of around $37^{\circ} \mathrm{C}$. Enterohemorrhagic E. coli has a growth range between 8 and $48^{\circ} \mathrm{C}$, and Aeromonas spp., between 4 and $45^{\circ} \mathrm{C}$ (Szewzyk et al., 2000). At temperatures exceeding maximum growth limits, the thermal death rates are high, such as for Campylobacter sp. that survive for only a few hours at temperatures exceeding their optimal range of $37^{\circ} \mathrm{C}$ (Szewzyk et al., 2000). As well as studying Legionella species, Stout et al. (1986) also investigated the $D$-values for species from other genera. At 60,70 and $80^{\circ} \mathrm{C}$, $P$. aeruginosa had $D$-values of $2 \cdot 6,1 \cdot 3$ and $0 \cdot 7$, respectively (Stout et al., 1986).

\section{Conclusions}

The results of this study show that after 5 min of exposure at 60 and $55^{\circ} \mathrm{C}$, respectively Salmonella, $P$. aeruginosa and $T_{\mathrm{VC}}$ at 22 and $37^{\circ} \mathrm{C}$ concentrations were reduced to zero. E. coli and faecal

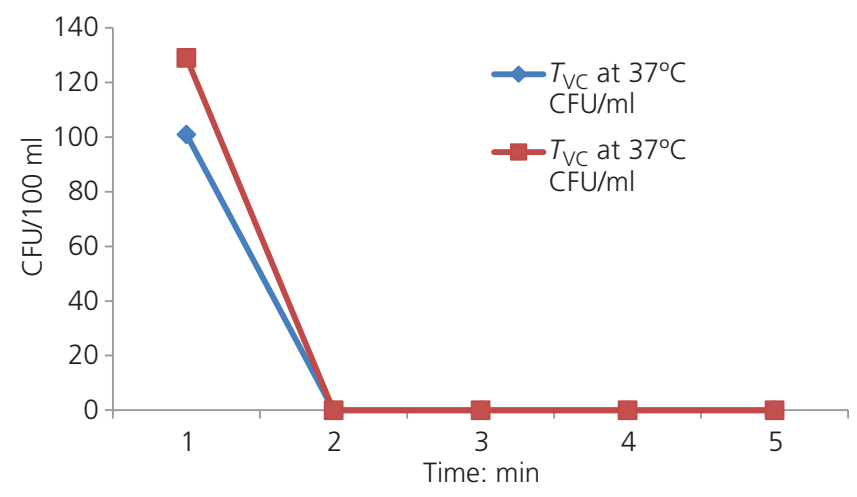

Figure 7. Thermal inactivation rates for $T_{\mathrm{VC}}\left(22\right.$ and $\left.37^{\circ} \mathrm{C}\right)$ at $60^{\circ} \mathrm{C}$

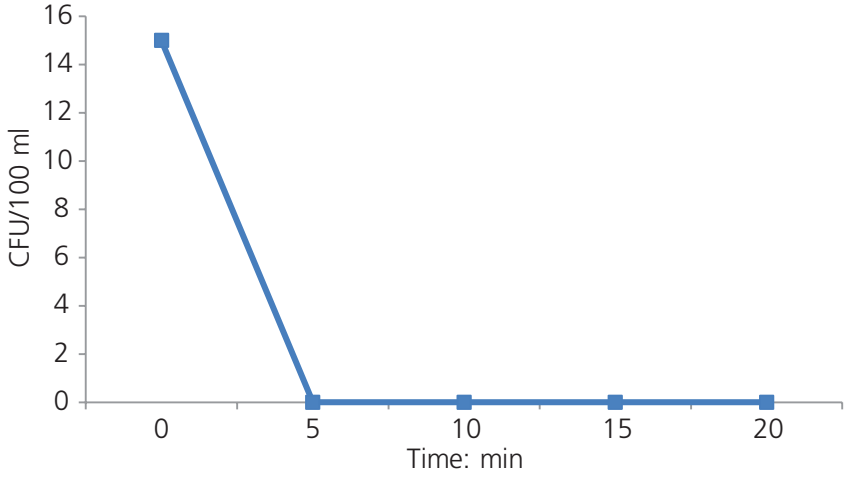

Figure 8. Thermal inactivation rates for $P$. aeruginosa at $60^{\circ} \mathrm{C}$

coliforms required $10 \mathrm{~min}$ of exposure at $55^{\circ} \mathrm{C}$ to reduce the population to zero and $5 \mathrm{~min}$ at $60^{\circ} \mathrm{C}$. This is in agreement with other international studies on domestic rainwater tanks and hot water systems (Coombes et al., 2003; Spinks, 2003). Thermal inactivation in RWH-fed hot water systems at a minimum of $60^{\circ} \mathrm{C}$, combined with the treatment train inherent within RWH systems, is likely to deliver water quality comparable to mains hot water. From the literature, the main risk to public health from hot water systems is not the water source but rather the operation, maintenance, age, location and temperature of the hot water system. Irish Standards require hot water systems to be maintained at temperatures at or above $60^{\circ} \mathrm{C}$. Hot water is stored at a minimum of $60^{\circ} \mathrm{C}$ and distributed so it reaches a minimum temperature of $50^{\circ} \mathrm{C}\left(55^{\circ} \mathrm{C}\right.$ in healthcare premises) within $1 \mathrm{~min}$ at outlets (HSE, 2013). The conclusion from this pilot study is that hot water systems supplied with RWH do not present an increased risk to health over hot water systems fed with mains water. Further studies in Ireland should be commissioned to characterise the RWH treatment train and the maintenance of RWH systems to establish appropriate indicator organisms and sampling points, and determine the efficiency of first flush devices.

\section{Acknowledgements}

This research is supported by the Dublin Institute of Technology, National Federation of Group Water Schemes, Department of Environment, Heritage and Local Government, Carlow County Council and the National Rural Water Monitoring Committee.

\section{REFERENCES}

ABS (Australian Bureau of Statistics) (1994) Regional Statistics, NSW. ABS, Canberra, Australia, ABS Catalogue no. 1304.1.

Ahmed W, Gardner T and Toze S (2011) Journal of Environmental Quality 40(1): 13-21.

American Public Health Association, American Waterworks Association and Water Environment Federation (2005) Standard Methods for the Examination of Water and Wastewater, 21st edn. American Public Health Association, American Waterworks Association and Water Environment Federation, Washington, DC, USA.

Borella P, Teresa Montagna M, Romano-Spica V et al. (2004) Legionella infection risk from domestic hot water. Emerging Infectious Diseases 10(3): 457-464. 
Journal of Environmental Engineering and Science

Volume 12 Issue JS2
Thermal inactivation analysis of waterrelated pathogens in domestic hot water systems

McCarton and O'Hogain
Brodribb R, Webster P and Farrell D (1995) Recurrent Campylobacter fetus subspecies bacteraemia in a febrile neutropaenic patient linked to tankwater. Communicable Diseases Intelligence 19: 312-313.

Coombes PJ (2002) Rainwater Tanks Revisited: New Opportunities for Urban Water Cycle Management. PhD thesis, University of Newcastle, Callaghan, Australia.

Coombes PJ (2015) Discussion on the 'influence of roofing materials and lead flashing on rainwater tank contamination by metals' by M. I. Magyar, A. R. Ladson, C. Daiper and V. G Mitchell. Australian Journal of Water Resources 19(1): 86-90.

Coombes PJ, Kuczera G, Kalma JD and Argue JR (2002) An evaluation of the benefits of source control measures at the regional scale. Urban Water 4(4): 307-320.

Coombes PJ, Kuczera GA and Kalma JD (2003) Economic, water quantity and quality impacts from the use of a rainwater tank in the inner city. Australian Journal of Water Resources 7(2): 111-120.

Coombes PJ, Dunstan RH, Spinks AT, Evans CA and Harrison TL (2006) Key messages from a decade of water quality research into roof collected rainwater supplies. Hydropolis Conference, Burswood Entertainment Complex, Perth, Australia.

Cunliffe DA (1998) Guidance of the use of rainwater tanks. National Environmental Health Forum Monographs. South Australian Health Commission, Adelaide, Australia, Water Series 3.

Dean J and Hunter PR (2012) Risk of gastrointestinal illness associated with the consumption of rainwater: a systematic review. Environmental Science \& Technology 46: 2501-2507.

Evans CA, Coombes PJ and Dunstan RH (2006) Wind, rain and bacteria: the effect of weather on the microbial composition of roof-harvested rainwater. Water Research 40(1): 37-44.

Evans CA, Coombes PJ, Dunstan RH and Harrison TL (2009) Extensive bacterial diversity indicates the potential operation of a dynamic micro-ecology within domestic rainwater storage systems. Science of the Total Environment 407: 5206-5215.

Franklin LJ, Fielding JE, Gregory J et al. (2009) An outbreak of Salmonella typhimurium 9 at a school camp linked to contamination of rainwater tanks. Epidemiology and Infection 137: 434-440.

Fuller CA, Martin TJ and Walters RP (1981) Quality Aspects of Water Stored in Domestic Rainwater Tanks (a Preliminary Study). Domestic Rainwater Tanks Working Party, Australia.

Gov.UK (2010) The Microbiology of Drinking Water - Part 8 - The Isolation and Enumeration of Aeromonas and Pseudomonas aeruginosa by Membrane Filtration. See https://www.gov.uk/ government/uploads/system/uploads/...PART8-231-apr15.pdf (accessed 20/09/2016).

Heyworth JS, Glonek G, Maynard EJ, Baghurst PA and Finlay-Jones $J$ (2006) Consumption of untreated tank rainwater and gastroenteritis among young children in South Australia. International Journal of Epidemiology 35(4): 1051-1058.

HSE (Health and Safety Executive) (2013) Code of Practice: Legionnaires' Disease: the Control of Legionella Bacteria in Water Systems, 4th edn. HSE Books, Sudbury, UK.

Idexx (2012a) The Microbiology of Drinking Water - Part 7. Idexx, Hoofddorp, the Netherlands. See https:/www.idexx.com/resource.../ water/quanti-disc-approval-modw-part-7-en.pdf (accessed 20/09/2016)

Idexx (2012b) Colilert ${ }^{\circledR}-18$. Idexx, Hoofddorp, the Netherlands. See http://www.idexx.com/view/xhtml/en_us/water/products/colilert-18.jsf (accessed 24/09/2016).

Jin G, Jeng HW, Bradford H and Englande AJ (2004) Comparison of E. coli, Enterococci, and fecal coliform as indicators for brackish water quality assessment. Water Environment Research 76(3): 245-255.

Kruse E, Wehner A and Wisplinghoff H (2015) Prevalence and distribution of Legionella spp in potable water systems in Germany, risk factors associated with contamination, and effectiveness of thermal disinfection. American Journal of Infection Control 44(4): 470-474, http://dx.doi.org/10.1016/j.ajic.2015.10.025.
Kus B, Kandasamy J, Vigneswaran S and Shon HK (2010) Analysis of first flush to improve the water quality in rainwater tanks. Water Science and Technology 61(2): 421-428.

Luo C, Walk ST, Gordon DM et al. (2011) Genome sequencing of environmental Escherichia coli expands understanding of the ecology and speciation of the model bacterial species. Proceedings of the National Academy of Sciences the United States of America 108(17): 7200-7205.

Lye DJ (2009) Rooftop runoff as a source of contamination: a review. Science of the Total Environment 407(21): 5429-5434.

Makin T (2014) Preheated Water Report: Water Regulations Advisory Scheme. See https://www.wras.co.uk/downloads/public_area/ publications/general/preheated water Nov 2014.pdf (accessed 20/09/ 2016).

Martin A, Coombes PJ, Harrison TL and Dunstan RH (2010) Changes in abundance of heterotrophic and coliform bacteria resident in stored water bodies in relation to incoming bacterial loads following rain events. Journal of Environmental Monitoring 12(1): 255-260.

Mobbs M (1998) Sustainable House. Choice Books, Sydney, Australia.

Morrow AC, Coombes PJ, Dunstan RH, Evans CA and Martin A (2007) Elements in tank water - comparisons with mains water \& effects of locality \& roofing materials. Rainwater and Urban Design Conference 2007, Sydney, Australia, pp. 830-837.

Morrow A, Dunstan H and Coombes PJ (2010) Elemental composition at different points of the rainwater harvesting system. Science of the Total Environment 408(20): 4542-4548.

Murrell WG and Stewart BJ (1983) Botulism in New South Wales, 1980-1981. Medical Journal of Australia 1(1): 13-17.

NHMRC (National Health and Medical Research Council) (1996) Australian Drinking Water Guidelines. NHMRC, Commonwealth of Australia, Sydney, Australia.

O'Hogain S, Reid A, McCarton L, Pender J and McNtyre N (2007) Water savings and rainwater harvesting - pilot project in Ireland. In Proceedings of the European Water and Wastewater Management (EWWM) Conference (Horan N (ed.)). Aqua Enviro, Wakefield, UK.

O'Hogain S, McCarton L, McIntyre N, Pender J and Reid A (2011) Physicochemical and microbiological quality of water from a pilot domestic rainwater harvesting facility in Ireland. Water and Environment Journal 25(4): 489-494.

O'Hogain S, McCarton L, McIntyre N, Pender J and Reid A (2012) Physicochemical and microbiological quality of harvested rainwater from an agricultural installation in Ireland. Water and Environment Journal Promoting Sustainable Solutions 26(1): 1-12.

Pflug IJ and Holcomb RG (1991) Principles of the thermal destruction of microorganisms. In Disinfection, Sterilization, and Preservation, 4th edn. (Block SS (ed.)). Lea \& Febiger, Philadelphia, PA, USA, pp. $85-128$.

Prescott LM, Harley JP and Klein DA (1993) Microbiology. Wm. C. Brown, Dubuque, IA, USA.

Rodrigo S, Sinclair M, Forbes A, Cunliffe D and Leder K (2011) Drinking rainwater: a double-blinded, randomized controlled study of water treatment filters and gastroenteritis incidence. American Journal of Public Health 101(5): 842-847.

Simmons G, Hope V, Lewis G, Whitmore J and Gao W (2001) Contamination of potable roof-collected rainwater in Auckland, New Zealand. Water Research 35(6): 1518-1524.

Spinks AT (2007) Water Quality, Incidental Treatment Train Mechanisms and Health Risks Associated with Urban Rainwater Harvesting Systems in Australia. PhD thesis, University of Newcastle, Callaghan, Australia. See http://urbanwatercyclesolutions.com (accessed 09/05/ 2017).

Spinks AT, Berghout B, Dunstan RH, Coombes PJ and Kuczera G (2005) Tank sludge as a sink for bacterial and heavy metals and its capacity for settlement, re-suspension and flocculation enhancement. 12th International Rainwater Catchment Systems Conference - Mainstream rainwater Harvesting, New Delhi, India. 
Journal of Environmental Engineering

and Science

Volume 12 Issue JS2
Thermal inactivation analysis of waterrelated pathogens in domestic hot water systems

McCarton and O'Hogain
Spinks AT, Dunstan RH, Harrison T, Coombes P and Kuczera G (2006) Thermal inactivation of water-borne pathogenic and indicator bacteria at sub-boiling temperatures. Water Research 40(6): 1326-1332.

Stout JE, Best MG and Yu VL (1986) Susceptibility of members of the family Legionellaceae to thermal stress: implications for heat eradication methods in water distribution systems. Applied and Environmental Microbiology 52(2): 396-399.
Szewzyk U, Szewzyk R, Manz W and Schleifer KH (2000) Microbiological safety of drinking water. Annual Review of Microbiology 54: 81-127.

Weinstein P, Macaitis M, Walker C and Cameron S (1993) Cryptosporidial diarrhoea in South Australia. Medical Journal of Australia 158: 117-119.

WHO (World Health Organization) (2003) Heterotrophic Plate Counts and Drinking Water Safety: the Significance of HPCs for Water Quality and Human Health. IWA Publishing, London, UK.

\section{How can you contribute?}

To discuss this paper, please submit up to 500 words to the editor at journals@ice.org.uk. Your contribution will be forwarded to the author(s) for a reply and, if considered appropriate by the editorial board, it will be published as a discussion in a future issue of the journal. 